\title{
EVALUATION OF MACROINVERTEBRATE DATA BASED ON AUTOECOLOGICAL INFORMATION
}

\author{
I. JUHÁSZ ${ }^{1 *}$
}

\section{Abstract}

Various data (biological, chemical, hydrological and morphological) have been gathered within the frame of the monitoring of the Water Framework Directive from 2007 in Hungary. This data only used a status assessment of certain water bodies in Hungary. The macroinvertebrates indicate many environmental factors well; therefore, they are very useful in detecting changes in the status of an environment. The main aim in this research was to investigate changes in environmental variables and decide how these variables cause big changes in the macroinvertebrate fauna. The macroinvertebrate data was processed using the ASTERICS 4.0.4 program. The program calculated some important metrics (i.e., microhabitat distributions, longitudinal zonation, functional feeding guilds, etc.). These metrics were compared with the chemical and hydrological data. The main conclusion is that if we have enough of a frequency and quality of macroinvertebrate data, we can understand changes in the environment of an ecosystem.

\section{Address}

1 Department of Water Conservation and River Basin Management, West-Transdanubian Water Directorate, Szombathely, Hungary, e-mail: juhasz.istvan@nyuduvizig.hu

* Corresponding author: juhasz.istvan@nyuduvizig.hu

\section{Key words}

- WFD monitoring,

- Aquatic macroinvertebrate,

- Autoecological information,

- Microhabitat,

- Longitudinal zonation,

- Functional feeding guilds.

\section{INTRODUCTION}

The aquatic macroinvertebrates are a very diverse group of organisms, which can be found in every type of water body. Macroinvertebrates have a broad taxonomic spectrum, different strategies of life histories (aquatic, amphibious), varied habitat preferences, a broad range of lifestyles, different lengths of generation time, diverse specialities of phenology, and variegated roles in the feeding web (Table 2); furthermore, some of them are protected or increasingly protected species (Müller, 2010). Therefore, they are excellent indicators and extremely useful in indicating the changes in an aquatic ecosystem; they play an important role in the qualification of water. Macroinvertebrates were used for biological water qualification for the first time in 1964; this qualification system was developed for the Trent River and is known as the Trent Biotic Index (TBI) (Woodiwiss, 1964). Many qualification systems have been developed, for example, the Hilsenhoff Index (HBI), the Biological Monitoring Working Party (BMWP), the French
Indice Biotique (IB), the Belgian Biotic Index (BBI) and the Biotic Index at the Secondary Education Level (BISEL) (Szita, 2012).

The Water Framework Directive (WFD) of the European Union came into effect on 22 December 2000; the main goal of the WFD for surface water bodies is to ensure a good ecological status. The most important element in the status assessment is the biological status as determined by the status of five groups of organisms (phytoplanktons, phytobenthos, macrophytes, benthic invertebrates, fishes) (European Parliament and Council, 2000). In Hungary it was necessary to develop new qualification systems for the assessment of the biological status of surface water bodies too. In the case of benthic invertebrates the $\mathrm{NQ}_{\mathrm{BAP}}$ qualification system was developed for the first River Basin Management Plan (RBMP) (Szilágyi, 2009).

$$
Q_{B A P}=\frac{\sum_{i=1}^{n} K_{i} S_{i} M_{i}}{P_{\max }}
$$


where:

$K_{i} \quad-$ is the character valence of the $\mathrm{i}$-th character taxon

$S_{i} \quad-$ is the significance multiplier of the i-th character taxon

$M_{i} \quad$ - is the quantitative multiplier of the i-th character taxon

$P_{\max }^{i}-$ is the maximized attainable total score in the case of a certain type of water body

The $\mathrm{NQ}_{\mathrm{BAP}}$ index is the normalized $\mathrm{Q}_{\mathrm{BAP}}$ index. This qualification system is based on a cluster analysis and the characterization of character species is based on the data of 485 Hungarian sample sites. The $\mathrm{NQ}_{\mathrm{BAP}}$ index shows a strong correlation with some organic load and plant nutrients (Szilágyi, 2009).

In 2011, the Hungarian Multimetric Makrozoobenton Index (HMMI) was developed for the assessment of the biological status of surface water bodies; this index was used in the second RBMP. The HMMI group contains six indices for different water bodies: $m$ - mountain water bodies, sc - small and medium-sized water bodies on hills, _lc - large-sized water bodies on hills, _sl - small and medium-sized lowland water bodies, 11 - large and extra large-sized lowland water bodies, and to - lake water bodies. Fox example, this is the calculation method for the HMMI $m$ index:

$$
H M M I_{-} m=\frac{E P_{E Q R}+S H_{E Q R}+A S P T_{E Q R}+L i t_{E Q R}}{4}
$$

where:

$$
\begin{aligned}
E P_{E Q R} & \text { - the normalized EQR value of the number of the } \\
& \text { Ephemeroptera and Plecoptera (EP) taxa } \\
S H_{E Q R} \quad \text { - the normalized EQR value of the Shannon diversity } & \\
A S P T_{E Q R} & \text { - the normalized EQR value of the Average Score per } \\
& \text { Taxon (ASPT): "represents the average tolerance } \\
& \text { score of all taxa within the community, and is calcu- } \\
& \text { lated by dividing the BMWP" (Mandaville, 2012) } \\
\text { Lit }_{E Q R} \quad \text { - the normalized EQR value of the proportion of taxa } & \text { preferring the litoral longitudinal zone }
\end{aligned}
$$

The HMMI index was developed within the frame of international ecological intercalibration in 2011. This index contains multimetric indices, for example, abundance, diversity, tolerance and functional guilds (Várbiró et al., 2015).

The indices presented characterize the status of a water body or a sampling point with only one number; thus we cannot examine the distribution of the properties of the habitat. Therefore, the main goal of this research was to collect data from a macroinvertebrate sampling, which was gathered within the frame of the WFD monitoring from 2007 to 2015. This data only used the assessment of the biological status of the water bodies; however, this macroinvertebrate data, along with knowledge of the ecological demands of the macroinvertebate taxa, can indicate the properties of a habitat that could evolve as a result of hydromorphological, chemical and biological changes.

\section{MATERIAL AND METHODS}

In this chapter the background of this research will be introduced from the data sources to the types of data processing.

\subsection{Study area}

The study area of this research is the operating area of the West-Transdanubian Water Directorate. In the first part of this research, the Répce upper surface water body in the Répce (Rabnitz) river was chosen to analyse the utility of the methods. This water body was chosen because most of the macroinvertebrate data from this water body is available and the distribution of this data is smooth.

The Répce upper water body is a natural water body; the type is $3 \mathrm{M}$ (hilly - medium slope - calcareous - coarse and medium-fine riverbed material - medium-sized catchment). There are two WFD surveillance monitoring sample points in the water body (Répcevis and Tompaládony), and there are two gauging stations in the two sampling points operated by the West-Transdanubian Water Directorate (Table 1).

Tab. 1 Main data of the two gauging stations in the Répce river

\begin{tabular}{lll}
\hline Name & Répce - Répcevis & $\begin{array}{l}\text { Répce - } \\
\text { Tompaládony }\end{array}$ \\
\hline Type of object & river station & river station \\
\hline Basic number & 000349 & 160077 \\
\hline Type of station & basic station & work station \\
\hline Basic catchment & Rába-Rábca & Rába-Rábca \\
\hline Catchment area $\left(\mathrm{km}^{2}\right)$ & 612 & 771 \\
\hline River & Répce & Répce \\
\hline River chainage $($ river $\mathrm{km})$ & 76.385 & 52.650 \\
\hline Zero point $(\mathrm{mBf})$ & 187.19 & 151.61 \\
\hline Bank & right bank & left bank \\
\hline EOVx $(\mathrm{m})$ & 235919 & 227101 \\
\hline EOVy $(\mathrm{m})$ & 471509 & 486982 \\
\hline Minimum water level $(\mathrm{cm})$ & -19 & 1 \\
\hline Maximum water level $(\mathrm{cm})$ & 470 & 303 \\
\hline Minimum discharge $\left(\mathrm{m}^{3} / \mathrm{s}\right)$ & 0.13 & 0.5 \\
\hline Maximum discharge $\left(\mathrm{m}^{3} / \mathrm{s}\right)$ & 95.2 & 33 \\
\hline Average discharge $\left(\mathrm{m}^{3} / \mathrm{s}\right)$ & 2.22 & 2.9 \\
\hline Settlement & Répcevis & Tompaládony \\
\hline Telemeter & yes & yes \\
\hline & & \\
\hline
\end{tabular}

\subsection{Macroinvertebrate data}

The macroinvertebrate data stem from the WFD biological monitoring. The data was gathered by the Laboratory of the Government Office of Győr-Moson-Sopron County, Hungary. The sampling method was the kick-and-sweep method with a standard pond net $(25 \mathrm{~cm}$ I $25 \mathrm{~cm}$ quadrat). The sampling is quantitative and representative because the placement of the 10 or 20 subsamples follows the distribution of the substrates and habitats in the riverbed (Figure 1). The identification occurred at the species level except in the case of the Oligochaeta and Diptera taxa (Várbiró et al., 2015).

\subsection{Data processing in the ASTERICS 4.0.4 program}

The data processing was performed using the ASTERICS 4.0.4 European stream assessment program (AQEM/STAR Ecological River Classification System). This program was developed by three projects: (1) The Development and Testing of an Integrated Assessment System for the Ecological Quality of Streams and Rivers throughout Europe using Benthic Macroinvertebrates (AQEM) project, (2) Standardisation of River Classifications (STAR): Frame- 


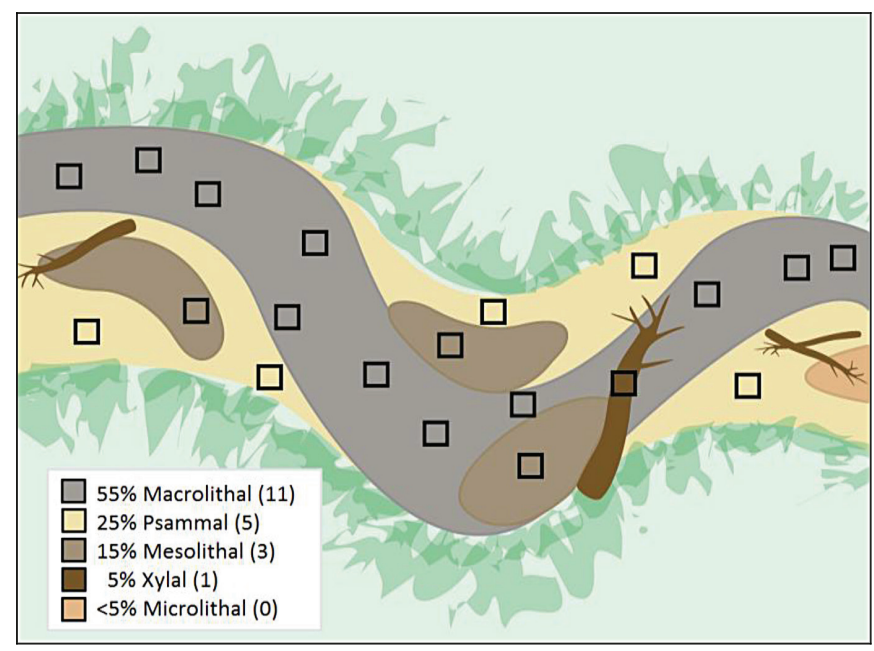

Fig. 1 Example of the placement of the subsamples in the case of the five (main) habitats (Ofenböck et al., ed., 2015)

work method for calibrating different biological survey results against an ecological quality classification to be developed for the Water Framework Directive project; and (3) the Assessment of benthic invertebrates (Extension and adaptation of the national assessment system for benthic invertebrates to international requirements) project. The program contains a taxa list of the macroinvertebrates with the autoecological information. The autoecological information stems from two important specialized works of literature: the Fauna
Aquatica Austriaca (Moog, 2002) and the Ökologische Typisierung der aquatischen Makrofauna (Schmedtje and Colling, 1996); furthermore, additional autoecologiacal information was gathered within the frame of the AQEM project (AQEM Consortium, 2002).

Before the taxa list could be imported into the program, the ID_ART identifier (Taxa identification number for internal use in the AQEM project) had to be checked in the case of each taxon, because the taxonomic level of the taxa in the sample data was not always the same in the operational taxa list. After the data import, "Europe" country, the "standard" stream type, and "unknown" stressor were chosen because calculating the ecological quality class was not essential. Thus the program calculated the necessary metrics to describe the changes in the properties of the habitats.

\subsubsection{Functional feeding guilds (percentage of community)}

Types of functional feeding guilds:

GRA: Grazers and scrapers

MIN: Miners

XYL: Xylophagous

SHR: Shredders

AFIL: Active filter feeders

PFIL: Passive filter feeders

PRE: Predators

PAR: Parasites

DET: Detritus feeders (gatherers, collectors)

OTH: Other feeding types

Tab. 2 Classification of the nutrition of aquatic insects (Andrikovics et al., 2003)

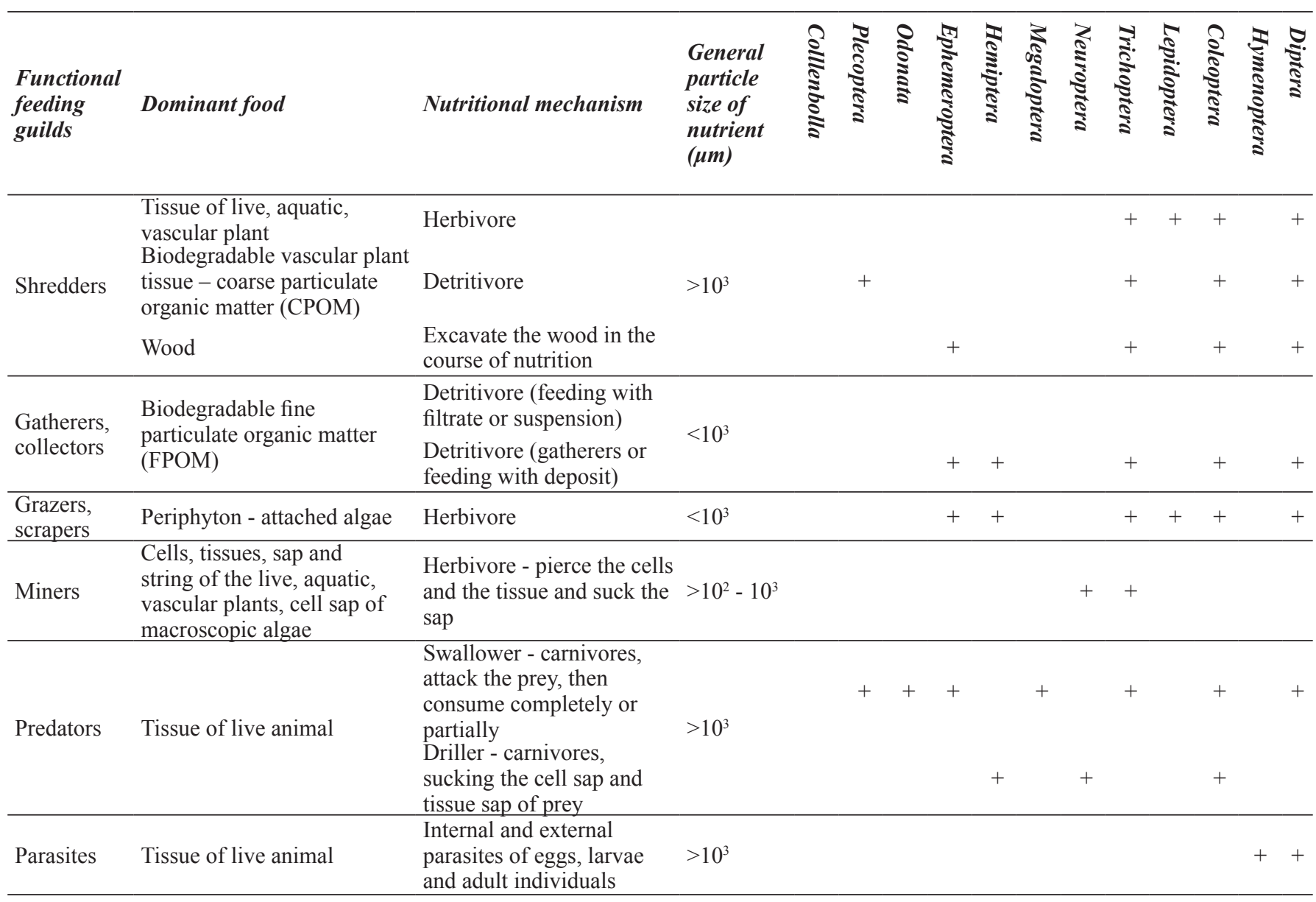




$$
F F G_{G r a}=\frac{\sum_{i=1}^{n} g r a^{i} h^{i}}{\sum_{i=1}^{n} h^{i}} \times \frac{100}{10}
$$

where:

$$
\begin{array}{ll}
F F G_{G r a} & - \text { is the proportion of grazer and scraper taxa in the sam- } \\
& \text { ple [\%]; } \\
g_{r a}{ }^{i} & - \text { is the functional feeding valence of the i-th taxon in the } \\
& \text { grazer and scraper guild [dimensionless, } x \text { from } 10] ; \\
h^{i} & \left.- \text { is the abundance of the i-th taxon [taxon } \cdot \mathrm{m}^{-2}\right] ; \\
n & - \text { is the number of the taxon }[\mathrm{db}] .
\end{array}
$$

The functional feeding guilds are suitable for assessing the impact of organic pollution, degradation in stream morphology and general degradation (AQEM Consortium, 2002). The following table (Table 2) shows the complex relation between the dominant food and nutritional mechanisms which determine the functional feeding guilds.

\subsubsection{Microhabitat preference (percentage of community preferring a certain microhabitat)}

Types of microhabitats:

ARG: Argyllal (silt, loam, clay; grain size $<0.002 \mathrm{~mm}$ )

PEL: Pelal (mud; grain size $0.002-0.063 \mathrm{~mm}$ )

PSA: Psammal (sand; grain size 0.063 - $2 \mathrm{~mm}$ )

AKA: Akal (fine to medium-sized gravel; grain size $0.2-2 \mathrm{~cm}$ )

LIT: Lithal (coarse gravel, stones, boulders; grain size $>2 \mathrm{~cm}$ )

PHY: Phytal (algae, mosses, macrophytes, including living parts of terrestrial plants)

POM: Particular Organic Matter (woody debris, CPOM, FPOM)

OTH: Other habitats (e.g., host of parasite)

$$
M h P_{A r g}=\frac{\sum_{i=1}^{n} a r g^{i} h^{i}}{\sum_{i=1}^{n} h^{i}} \times \frac{100}{10}
$$

where:

$M h P_{A r g}$ - is the proportion of taxa preferring the Argyllal microhabitat in the sample [\%];

$\arg ^{i} \quad-$ is the microhabitat preference valence of the i-th taxon in the Argyllal microhabitat [dimensionless, $x$ from 10];

$h^{i} \quad-$ is the abundance of the i-th taxon [taxon $\left.\cdot m^{-2}\right]$;

$n \quad-$ is the number of the taxon $[d b]$.

The microhabitat preference is suitable for assessing the impact of organic pollution and degradation in stream morphology (AQEM Consortium, 2002)

\subsubsection{Longitudinal zonation (percentage of community preferring a certain zone)}

Types of longitudinal zonation:

EUC: Eucrenal (spring region)

HYC: Hypocrenal (spring brook)

EP: Epirhithral (upper trout region)

MP: Metarhithral (lower trout region)

HR: Hyporhithral (grayling region)

EP: Epipotamal (barbel region)

MP: Metapotamal (brass region)

HP: Hypopotamal (brackish water region)
LIT: Litoral (lake and stream shorelines, ponds, etc.)

PRO: Profundal (bottom of stratified lakes)

$$
Z_{E u c}=\frac{\sum_{i=1}^{n} e u c^{i} h^{i}}{\sum_{i=1}^{n} h^{i}} \times \frac{100}{10}
$$

where:

$Z_{\text {Euc }}$ - is the proportion of taxa preferring a Eucrenal longitudinal zone in the sample [\%];

$e u c^{i}-$ is the longitudinal zone preference valence of the $\mathrm{i}$-th taxon in the Eucrenal longitudinal zone [dimensionless, $x$ from 10];

$h^{i} \quad$ - is the abundance of the $\mathrm{i}$-th taxon $\left[\operatorname{taxon} \cdot \mathrm{m}^{-2}\right]$;

$n-$ is the number of the taxon $[d b]$.

The longitudinal zonation preference is suitable for assessing the impact of organic pollution and degradation in stream morphology (AQEM Consortium, 2002).

\subsubsection{Current preference (percentage of community preferring a certain current velocity)}

Types of the current preferences:

LB: Limnobiont (occurring only in standing waters)

LP: Limnophill (preferably occurring in standing waters; avoids currents; rarely found in slowly flowing streams)

LR: Limno- to rheophill (preferably occurring in standing waters but regularly occurring in slowly flowing streams)

RL: Rheo- to limnophill (usually found in streams; prefers slowly flowing streams and lentic zones; also found in standing waters)

RP: Rheophill (occurring in streams; prefers zones with a moderate to high current)

RB: Rheobiont (occurring in streams; bound to zones with a high current)

IN: Indifferent (no preference for a certain current velocity)

$$
C u P_{L B}=\frac{\sum_{i=1}^{n} h_{L B}^{i}}{\sum_{i=1}^{n} h^{i}}
$$

where:

$C u P_{L B}$ - is the proportion of Limnobiont taxa in the sample [\%];

$h_{L B}{ }^{i}$-is the abundance of the i-th Limnobiont taxon [taxon $\left.\cdot \mathrm{m}^{-2}\right]$

$h^{i} \quad-$ is the abundance of the $\mathrm{i}$-th taxon $\left[\operatorname{taxon} \cdot \mathrm{m}^{-2}\right]$;

$n \quad-$ is the number of the taxon $[d b]$.

The current preference is suitable for assessing the impact of degradation in stream morphology (AQEM Consortium, 2002).

\subsubsection{Locomotion types (percentage of community)}

Types of the locomotion:

Swimming/skating: species, which float in lakes or passively drift in rivers

Swimming/diving: species, which swim or dive actively

Burrowing/boring: species, which burrow in soft substrates or bore in hard substrates

Sprawling/walking: species, which sprawl or walk actively with legs, pseodopods or on mucus 
(Semi) Sessil: species, which are tightened to hard substrates, plants or other animals

Other: other locomotion types like flying or jumping (mainly outside the water)

$$
\operatorname{LoM}_{s s}=\frac{\sum_{i=1}^{n} s s^{i} h^{i}}{\sum_{i=1}^{n} h^{i}} \times \frac{100}{10}
$$

where:

$$
\begin{aligned}
L o M_{s s} & \text { - is the proportion of taxa moving by swimming/skating in } \\
& \text { the sample [\%]; } \\
s s^{i} & - \text { is the locomotion valence of the i-th taxon moving by } \\
& \text { swimming/skating [dimensionless, } x \text { from } 10] ; \\
h^{i} & - \text { is the abundance of the i-th taxon }\left[\text { taxon } \cdot \mathrm{m}^{-2}\right] ; \\
n & - \text { is the number of the taxon }[\mathrm{db}] .
\end{aligned}
$$

Locomotion types are suitable for assessing the impact of organic pollution, degradation in stream morphology and acidification (AQEM Consortium, 2002).

\subsubsection{Saprobic valence}

Types of saprobic valences:

Xeno saprobic: Clean water (no organic pollution)

Oligo saprobic: Little organic pollution

Beta-meso saprobic: Moderately polluted

Alpha-meso saprobic: Heavily polluted

Poly saprobic: Extremely polluted

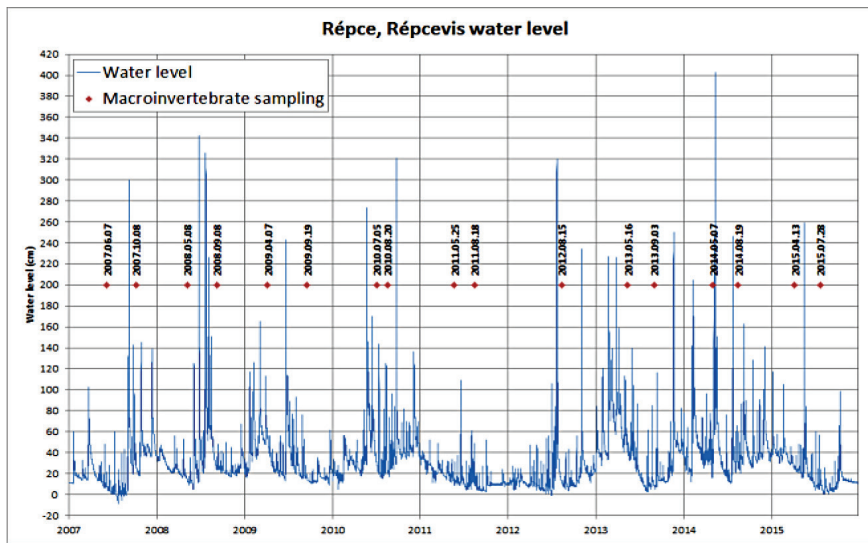

where:

$$
S V_{x}=\frac{\sum_{i=1}^{n} s_{x}^{i} h^{i}}{\sum_{i=1}^{n} h^{i}} \times \frac{100}{10}
$$

$S V_{x}$ - is the proportion of taxa preferring xeno saprobic in the sample [\%];

$s_{x}{ }^{i}$ - is the sabrobic valence of the $\mathrm{i}$-th taxon in the xeno saprobic [dimensionless, $x$ from 10];

$h^{i}$ - is the abundance the of i-th taxon $\left[\operatorname{taxon} \cdot \mathrm{m}^{-2}\right]$;

$n$ - is the number of the taxon $[d b]$.

The saprobic valence is suitable for assessing the impact of organic pollution (AQEM Consortium, 2002).

\section{RESULTS}

The following figure (Fig. 2) shows the changing of the water levels at Répcevis and Tompaládony and the macroinvertebrate sampling dates.

Figure 2 shows the difference in the dynamics of the changing of the water levels at Répcevis and Tompaládony. In the upstream (Répcevis) the flood waves are pointed and narrow, whereas in the Tompaládony, the flood waves are flatter, because Tompaládony is in the downstream, and there is a retarding reservoir at Gór between Tompaládony and Répcevis.

The nutrient forms (Figure 3 ) follow the graph of the water levels. We can find the features of the flood waves in the figure of the nutrient forms, especially in the case of the graphs of TOC, Total P and Total $\mathrm{N}$. This is caused by seepage from the catchment area. The trends of the nutrient forms are decreasing in Répcevis, but the trends of the $\mathrm{NO}_{3}-\mathrm{N}$ and the mineral $\mathrm{N}$ are a little bit rising in Tompaládony.

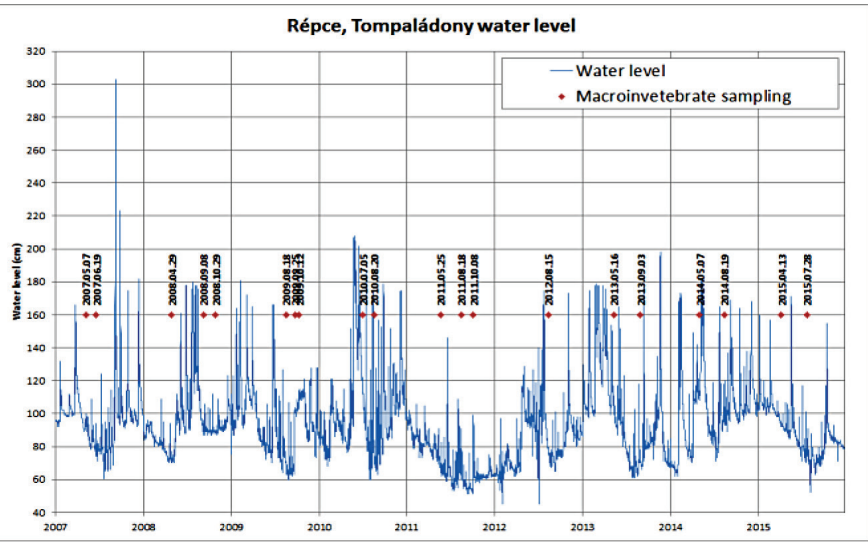

Fig. 2 Changing of water levels from 2007 to 2015 in the Répcevis and Tompaládony
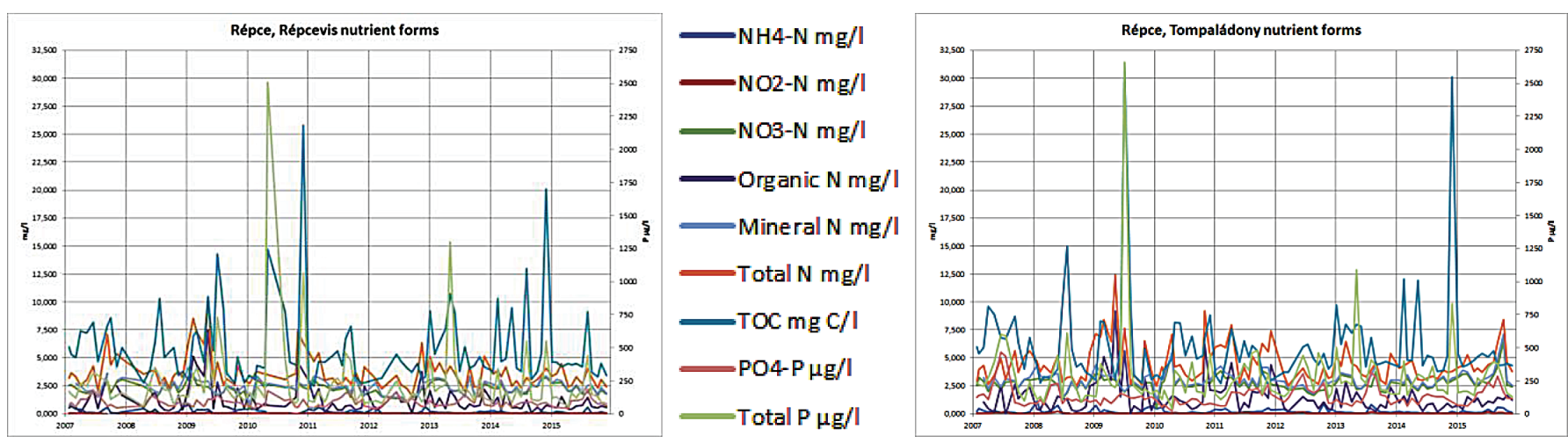

Fig. 3 Changing of nutrient forms from 2007 to 2015 in Répcevis and Tompaládony 

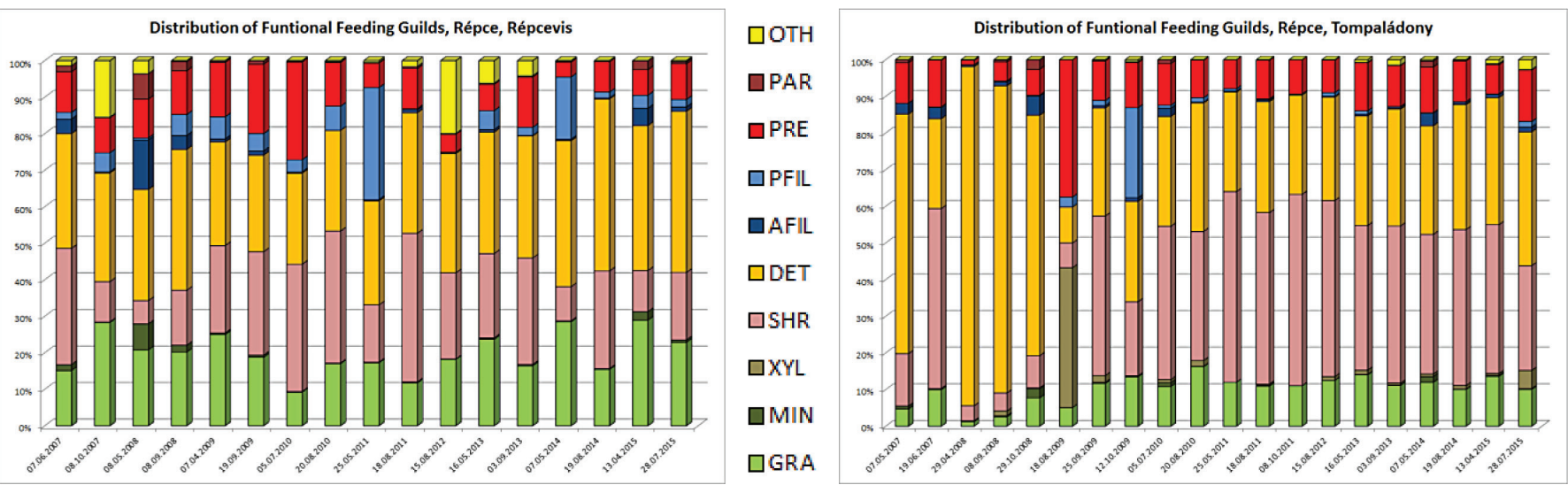

Fig. 4 Distribution of the functional feeding guilds from 2007 to 2015 in Répcevis and Tompaládony
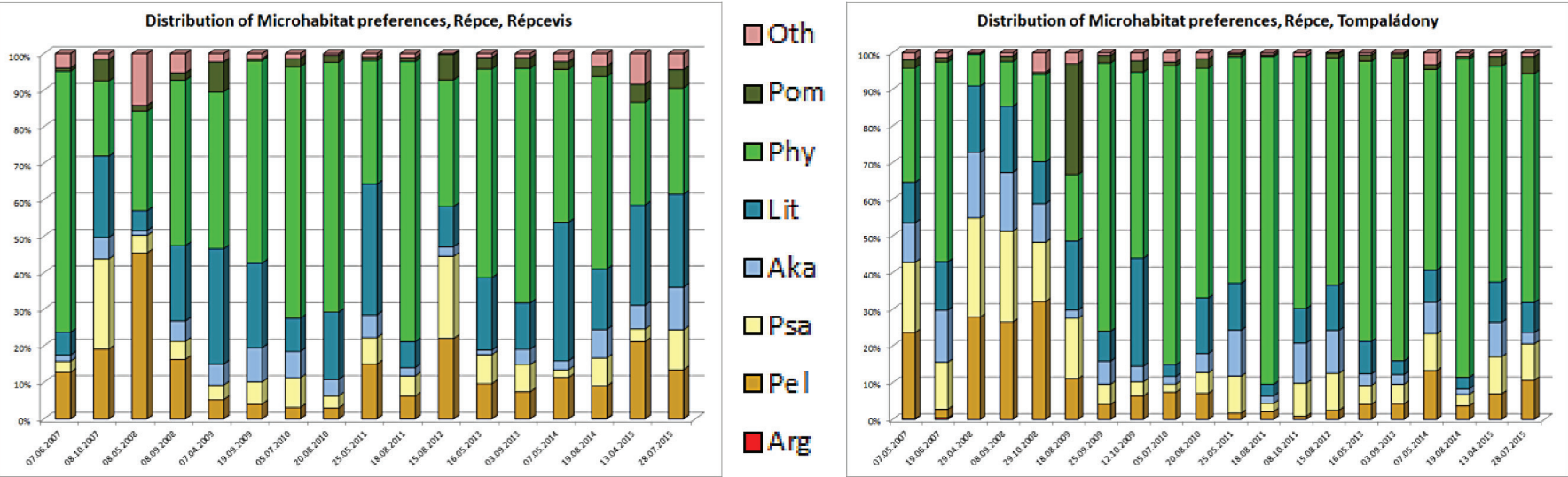

Fig. 5 Distribution of the microhabitat preferences from 2007 to 2015 at Répcevis and Tompaládony

\subsection{Metrics}

The following metrics were calculated by the Asterics 4.0.4 program from the autoecological information of the taxa, because no taxon has any autoecological information; therefore, just the scored taxa were used to prepare the distribution of $100 \%$.

\subsubsection{Functional feeding guilds}

The functional feeding guilds are the metrics most often used, because the status of the feeding web depends on a lot of environmental variables; therefore, they are very useful indicator metrics. They can be used to specify the longitudinal and temporal changes along a stream (Szita and Ambrus, 2016). The graphs (Figure 4) represent the difference between the two habitats. At Répcevis the rates of the grazer and the filter feeder taxa are higher versus the rates of the shredders, and the xylophagous taxa are higher at Tompaládony.

The trends of the grazer taxa's rates are rising in both sampling points; but, while the trends of the xylophagous, the passive filter feeder and the detritus feeder taxa's rates are rising in Répcevis, until the trends of the shredder and the predator taxa's distribution are rising in Tompaládony.

\subsubsection{Microhabitat preference}

The previous graphs (Figure 5) represent the changing of the microhabitats at the two sampling points which showed a strong relation between the floods and the seasons. After floods or in the spring, the rates of the mineral substrates (Lithal, Akal, Psammal and Pelal) are higher, but at the end of the summer, the rate of the phytal substrate is higher. At Répcevis the rates of the mineral substrates are higher than at Tompaládony, because in the upper section of the river, there are intensive floods which transport a lot of alluvium. The trend of the taxa's rate preferring phytal substrate is rising in Tompaládony, but the trends of the taxa's rates preferring the Lithal and the Akal substrates are rising in Répcevis.

\subsubsection{Longitudinal zonation preference}

The distribution of the longitudinal preferences (Figure 6) does not show a very great difference between the two stations. We can discover the natural processes: the preference for the Litoral and Potamal zones increases. We have found this result in the Ablánc stream (Juhász, 2008) too; this stream is a tributary of the Répce. While the trends of the taxa's rate preferring crenal, rhithral and potamal (except the hypopotamal) longitudinal zonation are rising in Répcevis; until in Tompaládony only the trends of the taxa's rates preferring crenal and rhithral longitudinal zonation are rising.

\subsubsection{Current preference}

The distribution of the current preferences (Figure 7) follows the graph of the water level. In a flood-free period the dominant current preference is the rheo- to limnobiont at Tompaládony, but in the case of Répcevis, the dominant preference is the rheo- to limnobiont and the rheophill together. After a flood event, the rate of indifferent cur- 

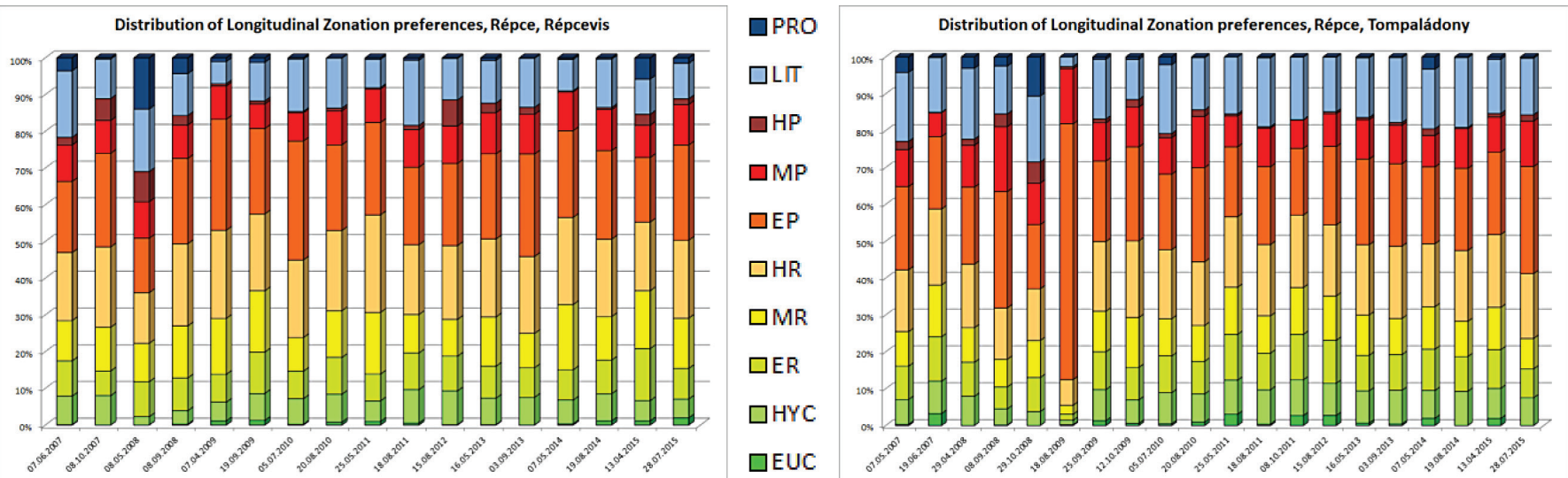

Fig. 6 Distribution of longitudinal zonation preferences from 2007 to 2015 at Répcevis and Tompaládony
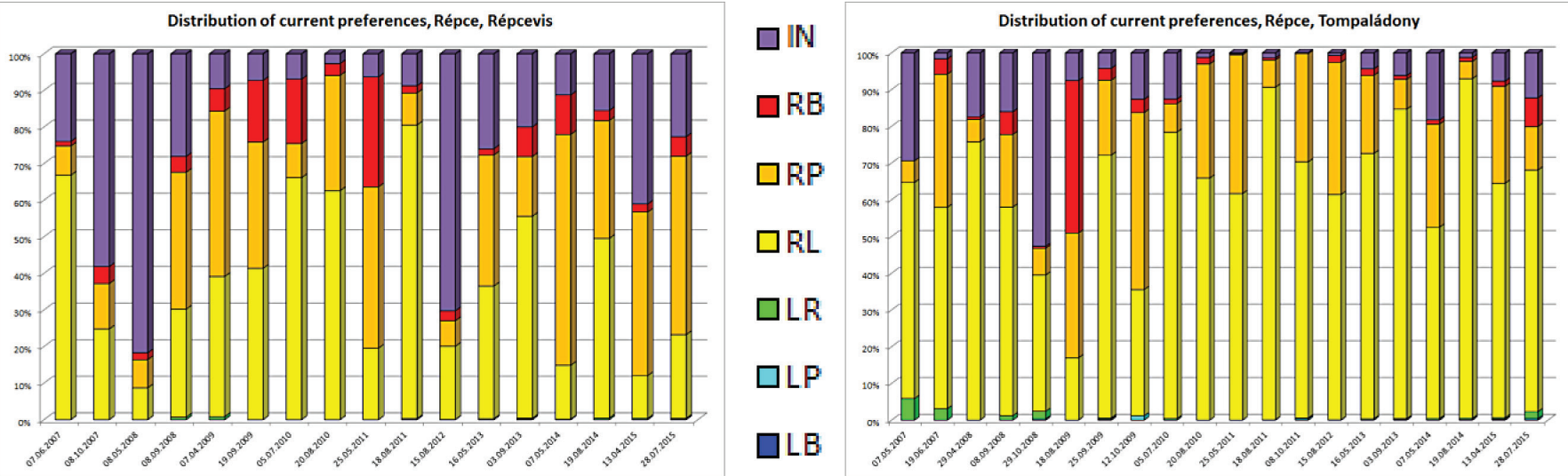

Fig. 7 Distribution of current preferences from 2007 to 2015 at Répcevis and Tompaládony
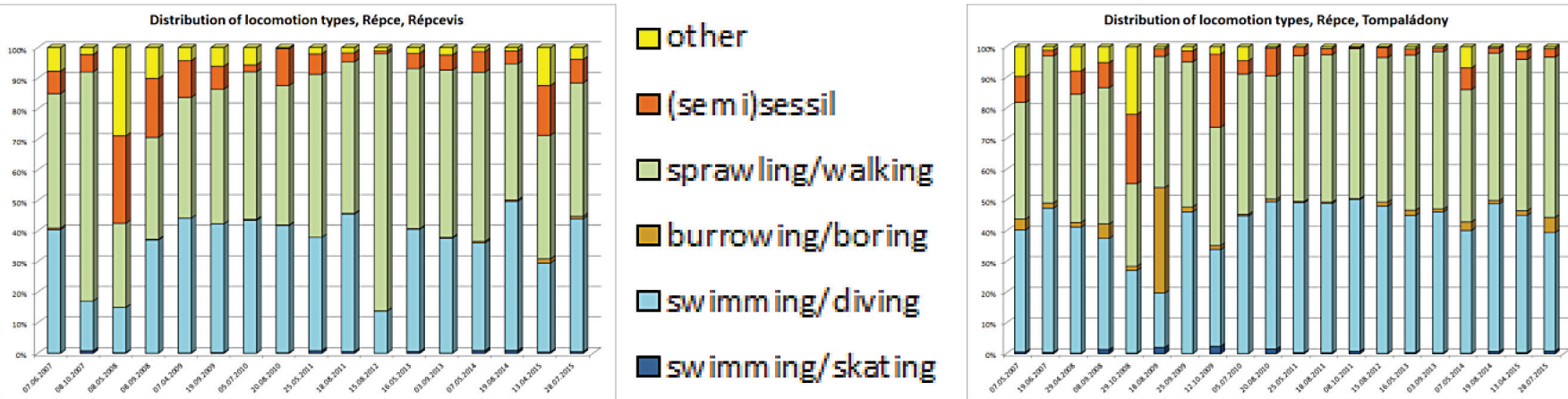

Fig. 8 Distribution of locomotion types from 2007 to 2015 at Répcevis and Tompaládony
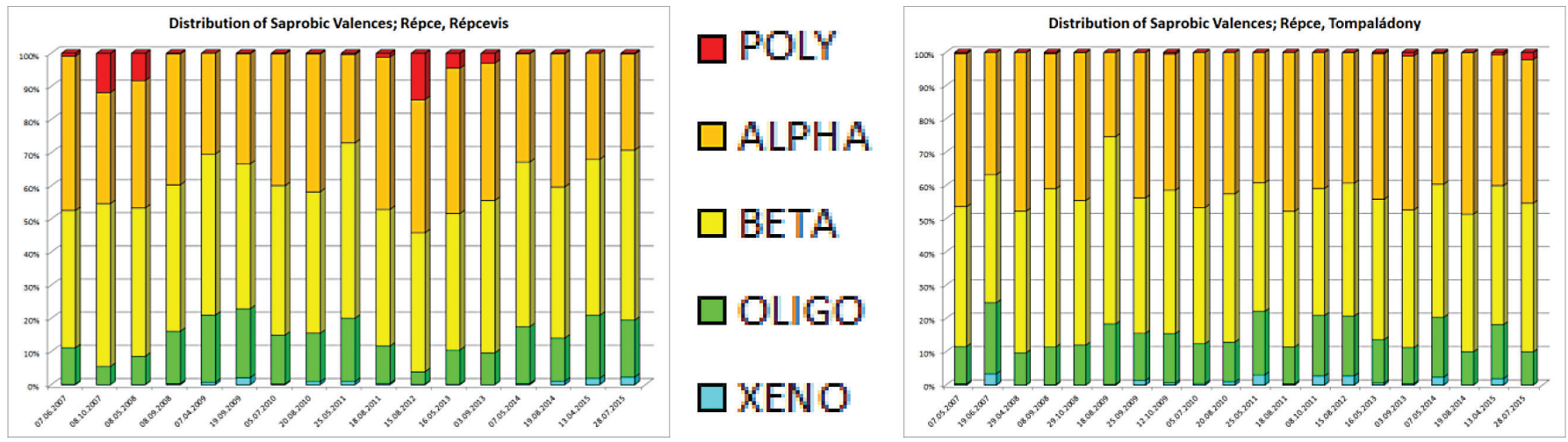

Fig. 9 Distribution of saprobic valences from 2007 to 2015 in Répcevis and Tompaládony 
rent preferences increases, which is the result of the drift effect. The trends of the Rheobiont taxa's rates are decreasing in both sampling points, furthermore the trends of the taxa's rates which have not preference for a certain current velocity are rising in both sampling points.

\subsubsection{Locomotion types}

The distribution of locomotion types is very similar at the two sampling points (Figure 8), and the rates are fairly constant in the examined period. The dominant locomotion types in this type of river are swimming or diving actively and sprawling or walking actively. The effect of the floods is only perceptible in the upper section (Répcevis), where the rate of the sprawling or walking locomotion type increases. The trends of the (Semi) Sessil taxa's rates are decreasing in both sampling points.

\subsubsection{Saprobic valence}

The saprobic valence is not a typical metric used to indicate the status of a habitat. Organic pollution causes changes in the distribution of substrates and the available food, so this metric is an indirect indicator.

The distribution of saprobic valences is very similar at the two sampling points (Figure 9). The dominant saprobic classes are the alpha- and the beta-mesosaprobic. We can find the effect of a flood event at Répcevis in this case too; after a big flood event, the rate of the polysaprobic increases, because in the case of floods, the returning water transports a lot of organic matter. At both sampling points in the case of the flood-free periods, the rate of the xenosaprobic class increases. While the trends of the taxa's rates preferring polysaprobic and alpha-meso saprobic classes are decreasing in Répcevis; until in Tompaládony the trends of the taxa's rates preferring polysaprobic and alpha-meso saprobic classes are rising.

\section{CONCLUSIONS}

The results of the research indicate that the two habitats in the Répce are very similar; the big difference is caused by the effect of the retarding reservoir in Gór, which reduces the impact of floods when it is operated. The results indicate that the effect of the reservoir decreases the variability of the microhabitat and increases the rate of the phytal substrate. Another conclusion is that the effect of floods does not just change the microhabitat (substrates), but organic pollution from the floodplain changes it due to the lack of a buffer zone, therefore the taxa which preferring the polysaprobic class increase after a big flood event. The results show strong link between a big flood event and the taxa which preferring mineral substrates, have not preference for a certain current velocity and sprawl or walk actively with legs, pseodopods or on mucus. The trends of the $\mathrm{NO}_{3}-\mathrm{N}$ and the mineral $\mathrm{N}$ are mildly rising in Tompaládony, because of this the trends of the taxa's rates preferring polysaprobic and alpha-meso saprobic classes are slightly rising also.

The data used are very useful to indicate the changing of the main properties of the aquatic environment which has been presented in this research, and in the case of the Ablánc stream (Juhász, 2007), for the functional feeding groups, longitudinal zones and saprobic valence too. Based on the results of this research, the metrics used can be helpful when comparing two or more habitats, showing the effects of floods, and examining the impact of a structure (for example, a reservoir dam).

In order to be able to use the metrics perfectly, the basic requirement is well-operated monitoring. However, monitoring systems have a lot of defects in Hungary. The majority of the water bodies have only one macroinvertebrate sampling every four years, which is not enough for the use of these metrics, because in the case of floods, the effect of a flood causes an instantaneous state, which is not described by the general state of water bodies. Another problem is the lack of synchronization of different types of sampling. Usually, the flow measurements and chemical samplings are coordinated in the case of small streams, where the Water Directorate does not have a telemetered gauging station. The biological sampling does not synchronize with either the chemical or the flow measurements; therefore, the results of the biological monitoring cannot be compared with the data of the two other monitorings. Thus the chemical monitoring and the flow measurement do not help with the interpretation of the results of the biological monitoring.

\section{Acknowledgements}

The Laboratory of the Government Office of Györ-Moson-Sopron County is thanked for the chemical and macroinvertebrates data; furthermore, the use of the hydrographical data and the basic data of the gauging stations from the West-Transdanubian Water Directorate is also greatly appreciated. 


\section{REFERENCES}

Andrikovics, S. - Kerekes, J. - Kriska, Gy. - Liszi, J. (2003) Limnológiai alapismeretek (Fundamentals of Limnology), Eszterházy Károly Főiskola Líceum Kiadó, Eger.

AQEM Consortium (2002) Manual for the application of the AQEM system, A comprehensive method to assess European streams using benthic macroinvertebrates, developed for the purpose of the Water Framework Directive. http://www.aqem.de/ftp/aqem manual.zip

European Parliament and Council (2000) Directive 2000/60/EC of the European Parliament and of the Council of 23 October 2000 establishing a framework for Community action in the field of water policy, Official Journal of the European Communities, L 327, v.43. 22/12/2000 P. $0001-0073$

Juhász, I. (2007) Az Ablánc-patak környezeti vizsgálata (Environmental Status evaluation of Ablánc stream), (diploma work), University of West Hungary, Faculty of Forestry, Sopron.

Juhász, I. (2008) Az Ablánc-patak környezeti vizsgálata (Environmental Status evaluation of Ablánc stream), Hidrológiai Közlöny 2009. (89. évf.) 6. sz. L. Hidrobiológus Napok, Magyar Hidrológiai Társaság. Budapest, pp. 19-21.

Müller, Z. (2010) A makrogerinctelen fauna Viz Keretirányelv szerinti vizsgálata a felsö- és középsö Ipolyvizgyüjtöjének Magyarországon elhelyezkedö részén (Researching of the macroinvertebrate fauna according to the WFD in the upper and middle sections of the Hungarian part of the Ipoly river catchment) (presentation), A Bükki Nemzeti Park Igazgatóság természeti értékeinek kutatása I.: „,Az Ipoly-vízgyűjtő vizes élőhelyeinek komplex felmérése, közösségi jegyzékeinek kidolgozása" (HUSK0801/066) Felsőtárkány, 2010.02.10. https://bnpi.hu/file/30/.

Mandaville, S. M. (2002) Benthic Macroinvertebrates in Freshwaters Taxa Tolerance Values, Metrics, and Protocols, Soil \& Water Conservation Society of Metro Halifax, Halifax 24 pp.

Moog, O. ed. (2002) Fauna Aquatica Austriaca, A comprehensive Species Inventory of Austrian Aquatic Organisms with Ecological Notes, $2^{\text {nd }}$ edition (2002), Federal Ministry of Agriculture, Forestry Environment and Water Management, Vienna, ISBN: 3-85 174-044-0

Ofenböck, T. - Moog, O. - Hartman, A. - Stubauer, I. ed. (2015) Leitfaden zur erhebung der biologishen qualitätselemente (Guidance for the investigation of biological quality elements), Teil A2 - Makrozoobenthos, Bundesministerium für Land- und Forstwirtschaft, Umwelt und Wasserwirtschaft, Sektion IV, Vienna. 23 pp.
Schmedtje, U. - Colling, M. (1996) Ökologische Typisierung der aquatischen Makrofauna (Ecological classification of the aquatic macro fauna).-Informationsberichte des Bayerischen Landesamtes für Wasserwirtschaft Heft 4/96 Bayerischen Landesamtes für Wasserwirtschaft, München.

Schmidt-Kloiber, A. - Graf, W. - Lorenz, A. - Moog, O. (2006) "The AQEM/STAR taxalist - a pan-European macro-invertebrate ecological database and taxa inventory"; The Ecological Status of European Rivers: Evaluation and Intercalibration of Assessment Methods, Springer, Dordrecht, pp. 325-342, doi: 10.1007/ s10750-006-0086-3.

Szilagyi, F. (2009) A felszíni vizek biológiai minösitésének továbbfejlesztése (Improvement of the biological qualification in surface water), Háttéranyag az országos VGT 5. fejezetéhez, 5-1. háttéranyag, ÖKO Zrt. vezette Konzorcium, Budapest.

Szita, R. (2012) A Rák-patak természetes és mesterséges szakaszainak összehasonlitó hidrobiológiai vizsgálata (Comparative hydro-biological research of the natural and artificial sections in Rák stream), (diploma work), University of West Hungary, Faculty of Forestry, Sopron.

Szita, R. - Ambrus, A. (2016) Longitudinal and temporal changes in functional feeding groups of aquatic macroinvertebrates along a given stream, Book of abstracts and programme, 2nd Central European Symposium for Aquatic Macroinvertebrate Research 3-8 July 2016, Mohács - Pécs, Hungary, p. 55, ISBN 978-96312-5936-0

Várbíró, G. - Boda, P. - Csányi, B. - Szekeres, J. (2015) Módszertani útmutató a makroszkopikus vízi gerinctelenek élölénycsoport VKI szerinti gyüjtéséhez és feldolgozásához (Methodological guide for the gathering and processing of the aquatic macroinvertebrate organisms group according to the WFD), Vízgyüjtő-gazdálkodási Terv - 2015, A Duna-vízgyüjtő magyarországi része, 6-1 háttéranyag: A felszíni vizek biológiai állapotértékelési rendszere. Országos Vízügyi Főigazgatóság, Budapest.

Woodiwiss, F. S. (1964) The Biological System of Stream Classification used by Trent River Board. Chemistry and Industry v. 11. London, pp. 443-447. 